\title{
Arterial stiffness in hematologic malignancies
}

This article was published in the following Dove Press journal:

OncoTargets and Therapy

3 March 2017

Number of times this article has been viewed

Abstract: Malignant and cardiovascular disorders are the top causes of mortality worldwide. This article reviews the main literature data and mechanisms linking hematologic malignancies and arterial stiffness, focusing on recent experimental and clinical results. Several links were found in hematologic malignancies between complete blood count and arterial stiffness. Chemotherapy, especially anthracyclines, cyclophosphamide and tyrosine kinase inhibitors, as well as radiotherapy and hematopoietic stem cell transplantation are the main known causes of arterial stiffness increase in hematologic malignancies. The mechanisms of arterial stiffness elevation in hematologic malignancies include an increased oxidative stress, impaired vascular wall homeostasis, endothelial dysfunction and apoptosis of endothelial cells, overexpression of inflammatory cytokines, accelerated atherosclerosis, increased blood viscosity and unstable platelet aggregates. Guidelines regarding cardiovascular health screening and cardiovascular risk scores are necessary for hematologic cancer survivors in order to improve prognosis and quality of life of the patients.

Keywords: arterial stiffness, complete blood count, leukemia, lymphoma, multiple myeloma, chemotherapy

\section{Introduction}

Malignant and cardiovascular disorders are among the leading causes of mortality worldwide. The number of long-term cancer survivors is increasing, considering the advancement in diagnostic tools and therapy. ${ }^{1,2}$ Cardiovascular disorders may increase mortality in cancer survivors, but the latency of the development of cardiovascular disorders has hampered large studies. ${ }^{3}$ The main cardiovascular abnormalities occurring in cancer survivors include heart failure, coronary heart disease, myocardial infarction, cardiomyopathy, pericarditis, conduction abnormalities, valvular disorders, hemorrhagic or ischemic stroke and vascular abnormalities, including peripheral arterial disease and venous thromboembolism. ${ }^{3-6}$ The increased risk of premature cardiac disease in cancer survivors is due to the overlap in risk factors for cancer and cardiovascular disease and the cardiotoxic effects of therapy. ${ }^{7}$ Metastases of several cancers are also associated with an increased risk of coronary heart disease. ${ }^{5}$ Stroke is common among cancer patients, especially those with leukemia, and several cancerrelated causes of stroke have been suggested, such as treatment-related side effects, compression or invasion of blood vessels, hemostatic activation or an alteration in blood viscosity due to the tumor, nonbacterial thrombotic endocarditis and cytokines and chemokines produced by tumor cells, inducing a proinflammatory reaction with prothrombotic and atherosclerotic effects, but there is no consensus about cancer as an independent risk factor for stroke. ${ }^{6}$

Arterial stiffness, the expression of reduced elastic properties of the arteries, predicts cardiovascular events. It is one of the earliest detectable signs of adverse structural

Correspondence: loana Mozos

Department of Functional Sciences,

"Victor Babes" University of Medicine

and Pharmacy, Tudor Vladimirescu Street

14, 300173 Timișoara, Romania

Email ioanamozos@yahoo.de (c)
hereby accept the Terms. Non-commercial uses of the work are permitted without any further permission from Dove Medical Press Limited, provided the work is properly attributed. For permission for commercial use of this work, please see paragraphs 4.2 and 5 of our Terms (https://www.dovepress.com/terms.php). 
and functional changes within the vessel wall. ${ }^{8}$ Changes in blood vessels occur much earlier than the clinical disease. ${ }^{9}$ Arterial stiffness may be assessed using pulse wave velocity (PWV) or augmentation index. Increased arterial stiffness is related to arteriosclerosis, atherosclerosis, increased vascular fibrosis, loss of elastic fibers and extensive vessel wall calcification ${ }^{10}$ and may serve as a screening method for the detection of pre-clinical cardiovascular disease.

\section{Aim}

It is critical to identify, as early as possible, any sign of cardiovascular disorders in cancer survivors.

The aim of the present article was to review the main literature data and mechanisms linking hematologic malignancies and arterial stiffness, focusing on recent experimental and clinical results.

\section{Complete blood count}

Complete blood count, an inexpensive, convenient and accessible test, has been recently associated with increased arterial stiffness, early arterial aging and cardiovascular risk in patients with hematologic malignancies. ${ }^{11}$

Anemia, common in chronic diseases, is an independent risk factor for cardiovascular complications, considering hypoxia, volume overload causing progressive cardiac enlargement and reduced blood viscosity causing a hyperdynamic state. ${ }^{12,13}$ Hemoglobin affects peripheral vascular resistance due to the effect on blood viscosity and caliber of peripheral arterioles. ${ }^{14}$ Montero et $\mathrm{al}^{15}$ concluded that arterial stiffness is strongly and inversely associated with the total volume of red blood cells in healthy individuals, suggesting that arterial stiffness may be involved in the regulation of erythropoiesis. Mozos and Mihaescu ${ }^{11}$ found a negative correlation between hemoglobin level and PWV in patients with hematologic malignancies, but blood viscosity could have been elevated in patients with a high leukocyte count, considering that leukocytes have a higher viscosity than erythrocytes. ${ }^{16}$ Not only anemia but micro- and macrocytosis were also found to be predictors of arterial stiffness and early arterial aging in hematologic malignancies. ${ }^{11}$

Increased white blood cell (WBC) count, as a consequence of the hematologic malignancy or a marker of systemic inflammation, was associated with atherosclerotic cardiovascular disease and arterial stiffness in several studies. ${ }^{17,18}$ Experimental inflammation increases arterial stiffness, suggesting a causative role, and anti-inflammatory therapy can reduce arterial stiffness. ${ }^{18}$ Neutrophil to lymphocyte ratio, calculated from complete blood count, is an inexpensive, accessible marker of inflammation, which may also be used in risk stratification of patients with cardiovascular diseases, including peripheral arterial occlusive diseases. ${ }^{19,20}$ It is also a marker of advanced, aggressive cancer, evidenced by increased tumor stage, nodal stage and number of metastatic lesions. ${ }^{21}$

Significant correlations and associations were found between WBC count and arterial stiffness, related, probably, to the high blood viscosity, especially in chronic granulocytic leukemia. ${ }^{16}$ Elevated blood viscosity was found to be a component of vascular shear stress, responsible for the rapid growth of atherosclerotic plaque and increasing plaque instability. ${ }^{22}$

Mean platelet volume, a marker of platelet activation, was previously positively correlated with arterial stiffness in healthy Chinese subjects and also in patients with hematologic malignancies. ${ }^{11,23}$

In hematologic malignancies, arterial function, especially PWV and arterial age, should be assessed in patients with anemia, micro- and macrocytosis, leukocytosis (increased neutrophil, basophil, monocyte, lymphocyte) and platelet count (Table 1). ${ }^{11}$

\section{Leukemia}

Leukemia is defined by uncontrolled proliferation of malignant nonfunctional blasts in the bone marrow, followed by their release in the general circulation. Childhood leukemia survivors have increased arterial stiffness, indicating risk of premature atherosclerosis and cardiovascular disorders, and efforts should be directed in order to early identify, monitor and manage cardiovascular risk factors in these patients. ${ }^{24}$ Chemotherapy itself may increase leukemia cell stiffness in acute lymphoblastic and myeloid leukemia, enabling vascular complications due to cell aggregation and obstruction of capillary-sized channels. ${ }^{25}$

Lymphocytes of chronic lymphocytic leukemia patients have a smaller cell volume, a higher stiffness and a higher median transit time compared to lymphocytes in healthy patients. ${ }^{26}$ Tyrosine kinase inhibitors, effective in therapy of patients with chronic myeloid leukemia, may cause vascular events. $^{27}$

\section{Lymphoma}

Lymphomas are defined by neoplastic proliferation of lymphoid cells, with the Sternberg-Reed cells as histological diagnosis elements in Hodgkin's lymphoma. Non-Hodgkin's lymphomas are more common, and immune mechanisms are frequently involved in the occurrence of vasculitis. ${ }^{28}$ Cardiovascular 
Table I Arterial stiffness in hematologic malignancies

\begin{tabular}{|c|c|c|c|}
\hline Factors associated with arterial stiffness & Findings & Number of patients & Reference \\
\hline $\begin{array}{l}\text { Pulse wave velocity (PWV) correlated with } \\
\text { neutrophil and basophil counts } \\
\text { PWV was associated with monocyte, } \\
\text { lymphocyte and platelet count } \\
\text { Augmentation index (Al) negatively } \\
\text { correlated with hemoglobin, hematocrit and } \\
\text { red blood cell count } \\
\text { Al was significantly associated with neutrophil } \\
\text { and platelet count }\end{array}$ & $\begin{array}{l}\text { Complete blood count could help } \\
\text { identify patients with increased arterial } \\
\text { stiffness in patients with hematologic } \\
\text { malignancies }\end{array}$ & $\begin{array}{l}29 \text { patients with hematologic } \\
\text { malignancies }\end{array}$ & $\begin{array}{l}\text { Mozos and } \\
\text { Mihaescu }\end{array}$ \\
\hline $\begin{array}{l}\text { Arterial stiffness was gradually elevated after } \\
\text { chemotherapy }\end{array}$ & $\begin{array}{l}\text { Cumulative chemotherapy could } \\
\text { exacerbate both arterial stiffness and } \\
\text { endothelial dysfunction }\end{array}$ & $\begin{array}{l}\text { A } 61 \text {-year-old man after vincristine- } \\
\text { Adriamycin (doxorubicin)- } \\
\text { dexamethasone chemotherapy for } \\
\text { relapsed multiple myeloma }\end{array}$ & Taniguchi et $\mathrm{al}^{32}$ \\
\hline $\begin{array}{l}\text { Increase of PWV was not influenced by } \\
\text { radiation therapy or chemotherapy }\end{array}$ & $\begin{array}{l}\text { Childhood cancer survivors } \geq 18 \text { years } \\
\text { had elevated PWV compared to } \\
\text { controls and established norms }\end{array}$ & $\begin{array}{l}68 \text { childhood cancer survivors } \\
\text { (lymphoma, leukemia, solid tumors) }\end{array}$ & Krystal et $\mathrm{al}^{62}$ \\
\hline Acute lymphoid leukemia survivors & $\begin{array}{l}\text { There is evidence of poorer vascular } \\
\text { health in acute lymphoid leukemia } \\
\text { survivors compared to healthy controls }\end{array}$ & $\begin{array}{l}\text { I } 6 \text { acute lymphoid leukemia } \\
\text { survivors, aged } 8-20 \text { years }\end{array}$ & Ruble et $\mathrm{al}^{64}$ \\
\hline $\begin{array}{l}\text { Aortic distensibility decreased after } \\
\text { anthracyclines }\end{array}$ & $\begin{array}{l}\text { A progressive decrease in aortic disten- } \\
\text { sibility after therapy with anthracyclines }\end{array}$ & 70 patients with lymphomas & Daskalaki et $\mathrm{al}^{41}$ \\
\hline $\begin{array}{l}\text { Radiotherapy was associated with increased } \\
\text { arterial stiffness (increased PWV and } \\
\text { decreased distensibility coefficient of the } \\
\text { common carotid artery) }\end{array}$ & $\begin{array}{l}\text { In Hodgkin's lymphoma survivors, } \\
\text { radiotherapy is associated with } \\
\text { increased arterial stiffness; this effect } \\
\text { is more evident when radiotherapy is } \\
\text { administered after } 35-40 \text { years of age }\end{array}$ & 82 Hodgkin's lymphoma survivors & $\begin{array}{l}\text { van Leeuwen- } \\
\text { Segarceanu et } \mathrm{al}^{31}\end{array}$ \\
\hline
\end{tabular}

diseases may be responsible for mortality after secondary malignancies in survivors of Hodgkin's and non-Hodgkin's lymphoma. ${ }^{29,30}$ Arterial stiffness was increased in Hodgkin's lymphoma survivors who underwent radiotherapy. ${ }^{31}$

\section{Multiple myeloma}

Multiple myeloma, the malignancy of plasma cells, characterized by bone marrow infiltration, osteolysis and injuries caused by paraproteinemia, is also associated with arterial stiffness.

Taniguchi et a ${ }^{32}$ reported a case of a patient with multiple myeloma undergoing therapy with vincristine-Adriamycin (doxorubicin)-dexamethasone, with progressive increase of arterial stiffness and multivessel coronary vasospasm, related to cumulative chemotherapy-induced endothelial damage and dysfunction.

An increased blood viscosity, an impaired platelet and coagulation function were also described in multiple myeloma due to the circulating monoclonal immunoglobulins ${ }^{33}$ and could be related to increased arterial stiffness. The thromboembolic risk is increased in multiple myeloma patients, especially due to novel antimyeloma agents, such as thalidomide associated with dexamethasone. ${ }^{33}$

\section{Chemotherapy}

Several vascular disorders are associated with chemotherapy, such as Raynaud's phenomenon, hypertension, myocardial infarction, stroke, peripheral vascular disease, hepatic veno-occlusive disease, vascular toxicity and angiogenesis inhibition. ${ }^{434-36}$ Alkylating agents, platinum compounds and anthracyclines have been considered as vascular toxicants. ${ }^{34}$ Experimental, in vivo evaluation of chemotherapy-induced vascular toxicity is challenging. ${ }^{34}$ Assessment of PWV and augmentation indices and monitoring of cardiovascular risk factors may identify asymptomatic subjects at high risk of cardiovascular events who could benefit from cardiovascular monitoring and cardioprotective approaches during and after chemotherapy, considering that cardiovascular disorders may appear after $10-15$ years of treatment completion. ${ }^{37}$ Acute vascular complications may occur as a result of vascular toxicity induced by chemotherapy, and they may progress into chronic conditions, such as atherosclerosis, responsible for the increased cardiovascular morbidity. ${ }^{34}$

Anthracycline therapy, the cornerstone in the treatment of several malignant disorders, especially breast cancer and hematologic malignancies, significantly improves the survival rate. Anthracyclines are known for their cardiotoxic 
effect, causing cardiac myocyte dysfunction or injury, left ventricular dilatation and diastolic dysfunction. ${ }^{38-40}$ The anthracyclines generally used are doxorubicin, epirubicin, pirarubicin and idarubicin. ${ }^{41}$ Cardiotoxicity has limited the use of anthracyclines, with cumulative dose limitations, considering that all are cardiotoxic to varying degrees, depending on the dosage, method of administration, age, cardiovascular history and previous and concomitant therapy. ${ }^{41}$

Several studies revealed structural arterial remodeling, increased arterial stiffness and endothelial dysfunction after anthracycline therapy in patients with hematologic malignancies (Table 2). A significant increase in aortic stiffness was found very soon, within 4 months of anthracycline therapy initiation, in a study including patients with lymphoma or leukemia, regardless of age, sex, diabetes, hypertension, hyperlipidemia or coadministration of other cytostatics. ${ }^{30}$ The rapid increase in PWV (1 month) suggests an acute process (endothelial dysfunction, increase in smooth muscle tone) rather than a chronic one (atherosclerosis, increased collagen synthesis). ${ }^{42}$ Daskalaki et $\mathrm{al}^{41}$ studied 70 patients with lymphomas who underwent therapy with anthracyclines, reporting a progressive, dose-dependent

Table 2 Chemotherapy and arterial stiffness

\begin{tabular}{|c|c|c|c|}
\hline $\begin{array}{l}\text { Therapy associated with } \\
\text { arterial stiffness }\end{array}$ & Findings & Number of patients & Reference \\
\hline $\begin{array}{l}\text { Vincristine-Adriamycin } \\
\text { (doxorubicin)- } \\
\text { dexamethasone }\end{array}$ & $\begin{array}{l}\text { Cumulative chemotherapy could exacerbate both } \\
\text { arterial stiffness and endothelial dysfunction and } \\
\text { result in transient frequent coronary vasospasm } \\
\text { even with clinically permissible doses of vincristine- } \\
\text { doxorubicin-dexamethasone chemotherapy or } \\
\text { thalidomide }\end{array}$ & $\begin{array}{l}\text { A } 61 \text {-year-old patient with multiple } \\
\text { myeloma and without coronary risk }\end{array}$ & Taniguchi et $\mathrm{al}^{32}$ \\
\hline $\begin{array}{l}\text { Radiotherapy, anthracyclines, } \\
\text { chemotherapy }\end{array}$ & $\begin{array}{l}\text { Radiation therapy, anthracycline dose and } \\
\text { chemotherapy exposure are not predictive of } \\
\text { increased pulse wave velocity (PWV) in childhood } \\
\text { cancer survivors }\end{array}$ & $\begin{array}{l}68 \text { childhood cancer survivors } \\
\text { (lymphoma, leukemia, solid tumors) }\end{array}$ & Krystal et $\mathrm{a}^{62}$ \\
\hline Anthracyclines (doxorubicin) & $\begin{array}{l}\text { A progressive decrease in aortic distensibility } \\
\text { occurs after therapy with anthracyclines }\end{array}$ & 70 patients with lymphomas & Daskalaki et $\mathrm{al}^{4 \mathrm{l}}$ \\
\hline $\begin{array}{l}\text { Anthracyclines (doxorubicin, } \\
\text { daunorubicin) }\end{array}$ & $\begin{array}{l}\text { Low to moderate doses of anthracycline-based } \\
\text { therapy are associated with the early development } \\
\text { of subclinical abnormalities of cardiac and vascular } \\
\text { functions }\end{array}$ & $\begin{array}{l}53 \text { patients with breast cancer, } \\
\text { leukemia or lymphoma }\end{array}$ & Drafts et $\mathrm{al}^{42}$ \\
\hline Anthracyclines & $\begin{array}{l}\text { Childhood cancer long-term survivors exposed to } \\
\text { anthracycline treatment exhibit a marked preclinical } \\
\text { vasculopathy, characterized by endothelial } \\
\text { dysfunction and increased arterial stiffness }\end{array}$ & $\begin{array}{l}96 \text { long-term survivors ( } 57 \text { males and } \\
39 \text { females, mean age } 14.9 \pm 5.3 \text { years) } \\
\text { of different childhood cancers }\end{array}$ & Jenei et $\mathrm{al}^{45}$ \\
\hline $\begin{array}{l}\text { Tyrosine kinase inhibitors } \\
\text { (imatinib, nilotinib) }\end{array}$ & $\begin{array}{l}\text { Relative risk for peripheral artery occlusive disease } \\
\text { determined by pathological ankle-brachial index in } \\
\text { nilotinib-treated patients compared to imatinib- } \\
\text { treated patients is } 10.3\end{array}$ & $\begin{array}{l}\text { I59 patients with chronic myeloid } \\
\text { leukemia receiving tyrosine kinase } \\
\text { inhibitors }\end{array}$ & Kim et $\mathrm{al}^{56}$ \\
\hline $\begin{array}{l}\text { Anthracyclines (doxorubicin, } \\
\text { epirubicin, daunorubicin) }\end{array}$ & $\begin{array}{l}\text { PWV value is significantly increased in patients } \\
\text { having received anthracyclines compared to the } \\
\text { control group. Increased arterial stiffness is present } \\
\text { irrespective of age, sex, body mass index, systolic } \\
\text { and diastolic blood pressures, mean arterial } \\
\text { pressure and heart rate }\end{array}$ & $\begin{array}{l}53 \text { children with lymphoma, } \\
\text { osteosarcoma, neuroblastoma, } \\
\text { synovial sarcoma, Wilms tumor, } \\
\text { rhabdomyosarcoma and other } \\
\text { tumors }\end{array}$ & Herceg-Cavrak et al ${ }^{9}$ \\
\hline $\begin{array}{l}\text { Anthracyclines (doxorubicin, } \\
\text { daunorubicin) }\end{array}$ & $\begin{array}{l}\text { A significant increase in aortic stiffness occurs } \\
\text { within } 4 \text { months of exposure to an anthracycline }\end{array}$ & $\begin{array}{l}40 \text { individuals who received an } \\
\text { anthracycline for the treatment of } \\
\text { breast cancer, lymphoma or leukemia } \\
\text { and I } 3 \text { age- and sex-matched } \\
\text { controls }\end{array}$ & Chaosuwannakit et $\mathrm{al}^{30}$ \\
\hline $\begin{array}{l}\text { Anthracyclines (doxorubicin, } \\
\text { daunorubicin) }\end{array}$ & Anthracyclines impair endothelial function & $\begin{array}{l}\text { I4 cancer patients (4-2I years) with } \\
\text { T-cell acute lymphocytic leukemia, } \\
\text { several types of sarcoma, primitive } \\
\text { neuroectodermal tumor, acute } \\
\text { myelogenous leukemia and lymphoma }\end{array}$ & Chow et al ${ }^{43}$ \\
\hline
\end{tabular}


decrease in aortic distensibility, and negative predictors of aortic distensibility were baseline age, systolic blood pressure, left atrial diameter and left ventricular ejection fraction. A decreased brachial artery reactivity, a measure of endothelial dysfunction, assessed by high-resolution ultrasound, was found in patients receiving doxorubicin or daunorubicin compared to controls. ${ }^{43}$ It is known that vasodilator changes in the brachial artery correlate well with coronary endothelial function, ${ }^{44}$ but the type of lymphoma did not correlate with the magnitude of aorta impairment. ${ }^{41}$ A positive correlation was found between doses of anthracyclines and reduction in thoracic aortic distensibility, ${ }^{30}$ but other authors did not confirm the correlation. ${ }^{9,42}$ In survivors of childhood cancer, who completed anthracycline therapy for a malignant disorder, aortic PWV was significantly higher compared to age- and sex-matched healthy controls, but no correlation was found between aortic PWV and the dose of anthracycline. ${ }^{9}$ Jenei et $\mathrm{al}^{45}$ compared 96 long-term survivors of different childhood cancer types and 72 age-, sex-, body weight- and blood pressure-matched controls, who underwent echocardiography and flow-mediated dilatation (FMD), revealing a greater FMD response and a lower stiffness index in healthy controls compared to anthracycline- or only chemotherapytreated patients. Higher triglyceride level, higher cumulative anthracycline dose and lower age at the start of therapy were independently associated with impairment of FMD response and aortic stiffness. ${ }^{45}$ Mozos and Mihaescu ${ }^{11}$ did not find significant associations between anthracycline use and PWV and early arterial aging in patients with hematologic malignancies, but only 5 patients underwent therapy with doxorubicin in the mentioned study. Currently, anthracyclines are limited to cumulative doses of $\leq 450 \mathrm{mg} / \mathrm{m}^{2}$ in order to reduce the incidence of cardiovascular events. ${ }^{42}$ Drafts et $\mathrm{al}^{42}$ demonstrated that 6 months after initiation of low- to moderate-dose anthracycline therapy, subclinical abnormalities of cardiac and vascular functions occurred, in parallel with worsening of quality of life. There may be thresholds of susceptibility to vascular dysfunction due to anthracycline therapy, and further research is needed in order to clarify the reversibility of the increase in arterial stiffness. ${ }^{4}$ Long-term persistence of their effects on vascular stiffness is not well known, but considering that increased PWV was recorded at least 1 year after chemotherapy completion, probably structural and functional vascular changes after anthracyclines persist for, at least, 1 year. ${ }^{9}$

Blood vessel walls were affected after doxorubicin administration due to decrease in endothelial-dependent relaxation, cell toxicity causing apoptosis of endothelial cells and possible early events in end-organ injury. ${ }^{34,43,46}$ The acute vascular effect of doxorubicin begins shortly after administration, with no recovery during the next 8 minutes of real-time imaging, and depends on the size of blood vessels (more prominent in smaller vessels). ${ }^{34}$ Doxorubicin-induced acute vascular toxicity may also involve increased plateletendothelial cell adhesion, mediated by glycoprotein IIb/IIIa; enhanced procoagulant activity of macrophages and endothelial cells; impaired membrane fluidity and protein $\mathrm{C}$ anticoagulant pathway and facilitated activation of tissue factor, resulting in microthrombi formation and compromised blood flow. ${ }^{47}$ Antiplatelet and anti-coagulant agents may protect the vessels against the detrimental effects of doxorubicin, but there is no clinical evidence for massive acute thrombotic events in the population treated with doxorubicin. ${ }^{47}$ The explanation is a platelet paradox effect of doxorubicin, enhancing platelet adhesion to endothelial cells on one hand and inhibiting platelet aggregation on the other hand, resulting in unstable endothelium-bound surface platelet aggregates that could reduce blood flow but not cause complete vessel occlusion. ${ }^{47}$ Reactive oxygen species are involved in directly induced platelet cytotoxicity after doxorubicin, resulting in thrombocytopenia following therapy, ${ }^{47-49}$ but may also be toxic to endothelial cells. ${ }^{47}$ Thrombocytopenia is also caused by bone marrow toxicity of doxorubicin. ${ }^{11}$ Endothelial cells exposed to doxorubicin exhibit a doserelated apoptosis in vitro and in vivo, mediated by caspase activation, with changes in the expression of the apoptosisrelated genes. ${ }^{50}$ Apoptosis, caused by doxorubicin, damages the vessels, causing excoriation, thrombosis and denudation of the endothelium in rabbit arteries..$^{50,51}$

Spironolactone, an aldosterone antagonist, able to block the renin-angiotensin-aldosterone system, has positive effect on cardiac fibrosis and remodeling, reducing cardiotoxicity of anthracyclines..$^{39}$ Considering the add-on therapy effects of mineralocorticoid receptor blockers in improving arterial stiffness in hypertensive patients and their effects on the attenuation of vascular inflammation and fibrosis, ${ }^{10}$ future research should focus also on the vascular benefits in patients with hematologic malignancies undergoing chemotherapy. In hypertensive patients treated with doxorubicin, drugs blocking the renin-angiotensin-aldosterone system are able to reduce not only blood pressure but also arterial stiffness. ${ }^{41}$

Arterial stiffness elevation due to anthracyclines is related to increased oxidative stress, impaired vascular collagen turnover and vascular wall homeostasis due to nuclear cellular actions of anthracyclines, endothelial dysfunction with rapid depletion of systemic NO levels, apoptosis of 
endothelial cells, overexpression of inflammatory cytokines and increased platelet-endothelial cell adhesion enabling microthrombi formation. ${ }^{4,11,30,41,47,52}$

Cyclophosphamide, an alkylating agent, may cause endothelial injury, enabling extravasation of toxic metabolites, ischemic injury of cardiomyocytes, coronary vasospasm and intracapillary microemboli. ${ }^{53}$ Endothelial damage may be also due to cumulative chemotherapy, associated with inactivation of endogenous NO synthase; reactive oxygen species derived from chemotherapy and impaired cell repair. ${ }^{32}$ Ding et $\mathrm{al}^{54}$ reported intravenous cyclophosphamide use as an independent risk factor for increased arterial stiffness in patients with systemic lupus erythematosus.

Tyrosine kinase inhibitors are very effective in the therapy of patients with chronic myeloid leukemia, ${ }^{27}$ but are commonly associated with cardiotoxicity. ${ }^{7}$ Vascular events, especially peripheral arterial occlusive disease, have been described in patients receiving nilotinib, bosutinib and ponatinib, especially if they had preexisting cardiovascular risk factors. ${ }^{27}$ Little is known about the incidence and predisposing factors of vascular events in long-term tyrosine kinase inhibitor-treated patients with chronic myeloid leukemia; probably, vascular events occur in a dose-dependent manner. ${ }^{27}$ Nilotinib may exert direct proatherogenic and antiangiogenic effects on endothelial cells, causing arterial stenosis and blocking recanalization and reperfusion after occurrence of arterial stenosis, and increases cholesterol and fasting glucose levels, despite high efficacy in treatment of patients with chronic myeloid leukemia. ${ }^{27,55}$ The proatherogenic effect of nilotinib has been confirmed by assessing the ankle brachial index in patients with chronic myeloid leukemia. ${ }^{56}$ Ponatinib counteracts endothelial cell growth and survival, but little is known about the molecular targets responsible for the effects on vascular endothelial cells. ${ }^{27}$

\section{Radiotherapy}

Several studies reported increased arterial stiffness due to radiotherapy in cancer, ${ }^{57-59}$ related to total body irradiation. ${ }^{60}$ Radiotherapy may also increase the activity of nuclear factor kappa B, associated with atherosclerosis. ${ }^{61}$

Radiotherapy is also associated with increased arterial stiffness in patients with Hodgkin's lymphoma, treated at an older age (after 35-40 years), related to accelerated atherosclerosis, endothelial dysfunction, presence of fibrous tissue, increased proteoglycan content and degeneration of the elastic fibers, induced by radiotherapy especially in smaller diameter arteries. ${ }^{31}$ Mediastinal radiotherapy can impair PWV, but not radiotherapy of the cervical lymph nodes in
Hodgkin's lymphoma. ${ }^{3}$ Aortic distensibility is inversely correlated with radiotherapy dose. ${ }^{57}$

Krystal et $\mathrm{al}^{62}$ evaluated 68 childhood cancer survivors, including patients who had lymphoma and leukemia, and found significantly higher values for PWV than that in controls, not related to radiation therapy or chemotherapy exposure. Vatanen et al ${ }^{59}$ demonstrated that long-term childhood cancer survivors treated with total body irradiation during early childhood display signs of early arterial aging during adulthood, including decreased arterial lumen size and an increased carotid intima-media thickness.

Metabolic syndrome, including central obesity, insulin resistance, hypertension, dyslipidemia and impaired carbohydrate metabolism, was found in children and adult cancer survivors, related to exposure to steroids, cranial radiation therapy, total body irradiation and hypogonadism. ${ }^{60}$

\section{Hematopoietic stem cell transplantation}

Hematopoietic stem cell transplantation, a curative option in several hematologic malignancies, is associated with an increased risk of health conditions, such as cardiovascular and endocrine disorders, metabolic syndrome and subsequent malignancies, requiring systematic and targeted follow-up. ${ }^{60,63}$ Early arterial mechanical changes were found at young age after allogenic stem cell transplantation in children, including lower distensibility of the common carotid artery, which decreased with time passed after transplantation. ${ }^{63}$

\section{Cardiovascular consequences of increased arterial stiffness}

An increased arterial stiffness causes a premature return of the reflected pulse wave in late systole, increasing central systolic blood pressure, pulse pressure and afterload of the left ventricle (causing left ventricular hypertrophy), and impairs coronary perfusion. ${ }^{9}$ An increased stiffness of the aorta is an independent predictor of cardiovascular events in the adult population, and assessing arterial stiffness in patients with hematologic malignancies, before and after therapy, enables prevention of cardiovascular complications. Poor vascular health was mentioned also in childhood and very young survivors of acute lymphoid leukemia. ${ }^{64}$

\section{Conclusion}

Hematologic malignancies impair vascular function and structure. Several cytostatics and radiotherapy are additional factors for the increased number of cardiovascular disorders in cancer survivors. Therefore, it is important to monitor arterial stiffness 
in patients with hematologic malignancies, especially if they are undergoing therapy with anthracyclines, cyclophosphamide or tyrosine kinase inhibitors; radiotherapy and stem cell transplantation or if they have cardiovascular risk factors. Vascular safety is an emerging challenge in patients with hematologic malignancies, and it is important to assess vascular stiffness before therapy, to consider the risk profile, to monitor metabolic and cardiovascular parameters and to develop protective mechanisms against toxic vascular effects of chemotherapy in order to prevent discontinuation of therapy.

Understanding the mechanisms linking arterial stiffness and hematologic malignancies enables development of prophylactic measures, multidisciplinary management and early intervention if necessary and may improve outcomes in oncology patients. Management of hematologic cancer survivors should include a multidisciplinary team, comprising a cardiologist and a hematologist, and long-term follow-up of patients is recommended. Complete blood count, a useful, inexpensive, widely available tool for management of patients with hematologic malignancies, can also provide useful information for cardiovascular complications.

Further studies to clarify the mechanisms and reversibility of chemotherapy-induced vascular toxicity are needed, enabling control of long-term vascular complications in cancer survivors. Guidelines regarding cardiovascular health screening and cardiovascular risk scores are necessary in cancer survivors in order to improve prognosis and quality of life of the patients.

\section{Disclosure}

The authors report no conflicts of interest in this work.

\section{References}

1. Barac A. Improving prediction of cardiovascular complications of cancer therapy: what does the future hold? Future Cardiol. 2015;11(4): 383-387.

2. Khouri MG, Klein MR, Velazquez EJ, Jones LW. Current and emerging modalities for detection of cardiotoxicity in cardio-oncology. Future Cardiol. 2015;11(4):471-484.

3. Van Leeuwen-Segarceanu EM, Bos WJW, Dorresteijn LDA, et al. Screening Hodgkin lymphoma survivors for radiotherapy induced cardiovascular disease. Cancer Treat Rev. 2011;37(5):391-403.

4. Vasu S, Hundley WG. Understanding cardiovascular injury after treatment for cancer: an overview of current uses and future directions of cardiovascular magnetic resonance. J Cardiovasc Magn Reson. 2013;15(1):66.

5. Zöller B, Ji J, Sundquist J, Sundquist K. Risk of coronary heart disease in patients with cancer: a nationwide follow-up study from Sweden. Eur J Cancer. 2012;48(1):121-128.

6. Zöller B, Ji J, Sundquist J, Sundquist K. Risk of haemorrhagic and ischaemic stroke in patients with cancer: a nationwide follow-up study from Sweden. Eur J Cancer. 2012;48(12):1875-1883.

7. Thavendiranathan P, Wintersperger BJ, Flamm SD, et al. cardiac MRI in the assessment of cardiac injury and toxicity from cancer chemotherapy. A systematic review. Circ Cardiovasc Imaging. 2013;6(6):1080-1091.
8. Erbel R, Aboyans V, Boileau C, et al. 2014 ESC guidelines on the diagnosis and treatment of aortic diseases. Document covering acute and chronic aortic diseases of the thoracic and abdominal aorta of the adult. Eur Heart J. 2014;35(41):2873-2926.

9. Herceg-Cavrak V, Ahel V, Batinica M, Matec L, Kardos D. Increased arterial stiffness in children treated with anthracyclines for malignant disease. Coll Antropol. 2011;35(2):389-395.

10. Shibata T, Tsutsumi J, Hasegawa J, et al. Effects of add-on therapy consisting of a selective mineralocorticoid receptor blocker on arterial stiffness in patients with uncontrolled hypertension. Intern Med. 2015;54(13):1583-1589.

11. Mozos I, Mihaescu R. Crosstalk between arterial stiffness, arterial age and blood count in hematologic malignancies. Jokull. 2015;65(9): 105-115.

12. Anderson J, Glynn IG, Newell J. The impact of renal insufficiency and anemia on survival in patients with cardiovascular disease: a cohort study. BMC Cardiovasc Disord. 2009;9:51-59.

13. Mozos I. Mechanisms linking red blood cell disorders and cardiovascular diseases. Biomed Res Int. 2015;2015:682054.

14. Chen H, Hua Q, Hou H. Association of hemoglobin with ambulatory arterial stiffness index in untreated essential hypertensive patients without anemia. Intern Med. 2011;50(22):2759-2765.

15. Montero D, Diaz-Cañestro C, Keiser S, Lundby C. Arterial stiffness is strongly and negatively associated with the total volume of red blood cells. Int J Cardiol. 2016;221:77-80.

16. Steinberg MH, Charm SE. Effect of high concentrations of leukocytes on whole blood viscosity. Blood. 1971;38(3):299-301.

17. Lee YJ, Lee JW, Kim JK, et al. Elevated white blood cell count is associated with arterial stiffness. Nutr Metab Cardiovasc Dis. 2009; 19(1):3-7.

18. Jain S, Khera R, Corrales-Medina VF, et al. Inflammation and arterial stiffness in humans. Atherosclerosis. 2014;237(2):381-390.

19. Bhat T, Teli S, Rijal J, et al. Neutrophil to lymphocyte ratio and cardiovascular diseases: a review. Expert Rev Cardiovasc Ther. 2013; 11(1):55-59.

20. Erturk M, Cakmak HA, Surgit O, et al. Predictive value of elevated neutrophil to lymphocyte ratio for long-term cardiovascular mortality in peripheral arterial occlusive disease. J Cardiol. 2014;64(5):371-376.

21. Guthrie GJ, Charles KA, Roxburgh CS, Horgan PG, McMillan DC, Clarke SJ. The systemic inflammation-based neutrophil-lymphocyte ratio: experience in patients with cancer. Crit Rev Oncol Hematol. 2013;88(1):218-230.

22. Cowan AQ, Cho DJ, Rosenson RS. Importance of blood rheology in the pathophysiology of atherothrombosis. Cardiovasc Drugs Ther. 2012; 26(4):339-348.

23. Wang $\mathrm{M}$, Cheng $\mathrm{J}$ [homepage on the Internet]. Overview and Management of Cardiac and Pulmonary Adverse Events in Patients with Relapsed and or Refractory Multiple Myeloma Treated with Single-Agent Carfilzomib; 2011. Available from: http://www. cancernetwork.com. Accessed February 14, 2017.

24. Dengel DR, Kelly AS, Zhang L, et al. Signs of earlier sub-clinical atherosclerosis in childhood cancer survivors. Pediatr Blood Cancer. 2014;61(3):532-537.

25. Lam WA, Rosenbluth MJ, Fletcher DA. Chemotherapy exposure increases leukemia cell stiffness. Blood. 2007;109(8):3505-3508.

26. Zheng Y, Wen J, Nguyen J, Cachia MA, Wang C, Sun Y. Decreased deformability of lymphocytes in chronic lymphocytic leukemia. Sci Rep. 2015;5:7613.

27. Valent P, Hadzijusufovic E, Schernthaner GH, Wolf D, Rea D, le Coutre P. Vascular safety issues in CML patients treated with BCR/ ABL1 kinase inhibitors. Blood. 2015;125(6):901-906.

28. De Sousa Lages A, Esperto H, Santos L, Carvalho A. Primary mediastinal (thymic) B-cell lymphoma presenting as cutaneous vasculitis. BMJ Case Rep. 2015;2015:bcr2014208804.

29. Aleman BM, van den Belt-Dusebout AW, Klokman WJ, et al. Longterm cause-specific mortality of patients treated for Hodgkin's disease. J Clin Oncol. 2003;21(18):3431-3439. 
30. Chaosuwannakit N, D'Agostino R Jr, Craig A, et al. Aortic stiffness increases upon receipt of anthracycline chemotherapy. J Clin Oncol. 2010;28(1):166-172.

31. van Leeuwen-Segarceanu EM, Dorresteijn LD, Vogels OJ, Biesma DH, Bos WJ. Arterial stiffness is increased in Hodgkin lymphoma survivors treated with radiotherapy. Leuk Lymphoma. 2013;54(8):1734-1741.

32. Taniguchi T, Nakamura T, Sawada T. Arterial stiffness, endothelial dysfunction and recurrent angina post-chemotherapy. $Q J$ Med. 2015;108(8): 653-655.

33. Coppola A, Tufano A, Di Capua M, Franchini M. Bleeding and thrombosis in multiple myeloma and related plasma cell disorders. Semin Thromb Hemost. 2011;37(8):929-945.

34. Bar-Joseph H, Stemmer SM, Tsarfaty I, et al. Chemotherapy-induced vascular toxicity-real-time in vivo imaging of vessel impairment. J Vis Exp. 2015;95:e51650.

35. Gautier V, Mirault T, Azarine A, et al. Peripheral artery occlusive disease of the lower limbs: rapid aggravation in a patient taking nilotinib for chronic myeloid leukemia. J Mal Vasc. 2015;40(4):231-239.

36. Poreba M, Gac P, Usnarska-Zubkiewicz L, et al. Endothelial function in patients with hematologic malignancies undergoing high-dose chemotherapy followed by hematopoietic stem cell transplantation. Cardiovasc Toxicol. 2016;16(2):156-162.

37. Mozos I, Mihaescu R. Pulse wave velocity and central hemodynamic indices in patients with malignant solid tumors. Jokull. 2015;65(12):200-214.

38. Mizia-Stec K, Goscinska A, Mizia M, et al. Anthracycline chemotherapy impairs the structure and diastolic function of the left ventricle and induces negative arterial remodeling. Kardiol Pol. 2013;71(7):681-690.

39. Akpek M, Ozdogru I, Sahin O, et al. Protective effects of spironolactone against anthracycline-induced cardiomyopathy. Eur J Heart Fail. 2015;17(1):81-89.

40. Christenson ES, James T, Agrawal V, Park BH. Use of biomarkers for the assessment of chemotherapy-induced cardiac toxicity. Clin Biochem. 2015;48(4-5):223-235.

41. Daskalaki M, Makris T, Vassilakopoulos T, et al. Effects of anthracyclines on aortic distensibility in patients with lymphomas: a prospective study. Hellenic J Cardiol. 2014;55(3):191-196.

42. Drafts BC, Twomley KM, D’Agostino R Jr, et al. Low to moderate dose anthracycline-based chemotherapy is associated with early noninvasive imaging evidence of subclinical cardiovascular disease. JACC Cardiovasc Imaging. 2013;6(8):877-885.

43. Chow AY, Chin C, Dahl G, Rosenthal DN. Anthracyclines cause endothelial injury in pediatric cancer patients: a pilot study. $J$ Clin Oncol. 2006;24(6):925-928.

44. Anderson TJ, Uehata A, Gerhard MD, et al. Close relation of endothelial function in the human coronary and peripheral circulations. $\mathrm{J} \mathrm{Am} \mathrm{Coll}$ Cardiol. 1999;26(5):1235-1241.

45. Jenei Z, Bárdi E, Magyar MT, Horváth A, Paragh G, Kiss C. Anthracycline causes impaired vascular endothelial function and aortic stiffness in long term survivors of childhood cancer. Pathol Oncol Res. 2013;19(3):375-383.

46. Murata T, Yamawaki H, Yoshimoto R, et al. Chronic effect of doxorubicin on vascular endothelium assessed by organ culture study. Life Sci. 2001;69(22):2685-2695.

47. Ben Aharon I, Bar Joseph H, Tzabari M, et al. Doxorubicin-induced vascular toxicity-targeting potential pathways may reduce procoagulant activity. PLoS One. 2013;8(9):e75157.

OncoTargets and Therapy

\section{Publish your work in this journal}

OncoTargets and Therapy is an international, peer-reviewed, open access journal focusing on the pathological basis of all cancers, potential targets for therapy and treatment protocols employed to improve the management of cancer patients. The journal also focuses on the impact of management programs and new therapeutic agents and protocols on
48. Woodley-Cook J, Shin LY, Swystun L, Caruso S, Beaudin S, Liaw PC. Effects of the chemotherapeutic agent doxorubicin on the protein $\mathrm{C}$ anticoagulant pathway. Mol Cancer Ther. 2006;5(12):3303-3311.

49. Kim EJ, Lim KM, Kim KY, et al. Doxorubicin-induced platelet cytotoxicity: a new contributory factor for doxorubicin-mediated thrombocytopenia. J Thromb Haemost. 2009;7(7):1172-1183.

50. Wu S, Ko YS, Teng MS, et al. Adriamycin-induced cardiomyocyte and endothelial cell apoptosis: in vitro and in vivo studies. $J \mathrm{Mol}$ Cell Cardiol. 2002;34(12):1595-1607.

51. Durand E, Scoazec A, Lafont A, et al. In vivo induction of endothelial apoptosis leads to vessel thrombosis and endothelial denudation. Circulation. 2004;109(21):2503-2506.

52. Duquaine D, Hirsch GA, Chakrabarti A, et al. Rapid-onset endothelial dysfunction with adriamycin: evidence for a dysfunctional nitric oxide synthase. Vasc Med. 2003;8(2):101-107.

53. Yeh ET, Bickford CL. Cardiovascular complications of cancer therapy. Incidence, pathogenesis, diagnosis and management. J Am Coll Cardiol. 2009;53(24):2231-2247.

54. Ding F, Ye Y, Li M, et al. Incidence and associated risk factors of arterial stiffness in patients with systemic lupus erythematosus. Zhounghua Xin Xue Guan Bing Za Zhi. 2015;43(1):56-61.

55. Larson RA, Hochhaus A, Hughes TP, et al. Nilotinib vs imatinib in patients with newly diagnosed Philadelphia chromosome-positive chronic myeloid leukemia in chronic phase: ENESTnd 3-year follow-up. Leukemia. 2012;26(10):2197-2203.

56. Kim TD, Rea D, Schwarz M, et al. Peripheral artery occlusive disease in chronic phase chronic myeloid leukemia patients treated with nilotinib or imatinib. Leukemia. 2013;27(6):1316-1321.

57. Kilicaslan B, Piskin GD, Susam I, et al. Effect of radiotherapy on impaired aortic elasticity and stiffness in patients with breast cancer. Angiology. 2014;65(7):643-648.

58. Gujral DM, Shah BN, Chahal NS, et al. Arterial stiffness as a biomarker of radiation-induced carotid atherosclerosis. Angiology. 2016;67(3): 266-271.

59. Vatanen A, Sarkola T, Ojala TH, et al. Radiotherapy-related arterial intima thickening and plaque formation in childhood cancer survivors detected with very-high resolution ultrasound during young adulthood. Pediatr Blood Cancer. 2015;62(11):2000-2006.

60. Scott Baker K, Armenian S, Bhathia S. Long-term consequences of hematopoietic stem cell transplantation: current state of the science. Biol Blood Marrow Transplant. 2010;16(1 suppl):S90-S96.

61. Halle M, Gabrielsen A, Paulsson-Berne G, et al. Sustained inflammation due to nuclear factor-kappa B activation in irradiated human arteries. J Am Coll Cardiol. 2010;55(12):1227-1236.

62. Krystal JL, Reppucci M, Mayr T, et al. Arterial stiffness in childhood cancer survivors. Pediatr Blood Cancer. 2015;62(10):1832-1837.

63. Turanlahti MI, Taskinen M, Saarinen-Pihkala U, et al. Time-related arterial changes after allogenic hematopoietic stem cell transplantation in children. Pediatr Res. 2013;73(6):777-782.

64. Ruble K, Davis CL, Han HR. Endothelial health in childhood acute lymphoid leukemia survivors: pilot evaluation with peripheral artery tonometry. J Pediatr Hematol Oncol. 2015;37(2):117-120.

\section{Dovepress}

patient perspectives such as quality of life, adherence and satisfaction The manuscript management system is completely online and includes a very quick and fair peer-review system, which is all easy to use. Visit http://www.dovepress.com/testimonials.php to read real quotes from published authors. 